\title{
Effect of Nitrogen Addition on Soil Respiration in a Larch Plantation
}

\author{
Jiang Zhu, Fengfeng Kang, Jing Chen, Xiaoqin Cheng, Hairong Han* \\ Forestry College, Beijing Forestry University, Beijing 100083, China
}

Received: 9 September 2016

Accepted: 13 December 2016

\begin{abstract}
Knowledge about the impact of nitrogen $(\mathrm{N})$ addition on soil respiration $(R \mathrm{~s})$ is critical for understanding soil carbon $(\mathrm{C})$ balance and its responses to climate change. We conducted a long-term field experiment to evaluate the response of $R s$ to $\mathrm{N}$ addition in a larch (Larix principis-rupprechtii) plantation during the growing season in northern China. We applied four $\mathrm{N}$ (in the form of $\mathrm{NH}_{4} \mathrm{NO}_{3}$ ) levels, i.e., control (N0: $0 \mathrm{~g} \mathrm{~N} \mathrm{~m}^{-2}$ year ${ }^{-1}$ ), low-N (N1: $5 \mathrm{~g} \mathrm{~N} \mathrm{~m}^{-2}$ year-1 $^{-1}$, medium-N (N2: $10 \mathrm{~g} \mathrm{~N} \mathrm{~m}^{-2}$ year ${ }^{-1}$ ), and high-N (N3: $15 \mathrm{~g} \mathrm{~N} \mathrm{~m}^{-2}$ year $^{-1}$ ) monthly starting in June 2015. The results showed that $\mathrm{N}$ addition - especially $\mathrm{N} 2$ and N3 levels - significantly stimulated $R \mathrm{~s}$. N1 and N2 levels resulted in the increase of $R \mathrm{~s}$ in a short time, whereas the duration of $\mathrm{N} 3$ level can last across the whole month or at least 10 days. The results highlight the need for improving the $R s$ sampling interval after $\mathrm{N}$ addition to ensure more accurate evaluation of $\mathrm{C}$ emission. Soil temperature and soil moisture together explained more variations of $R \mathrm{~s}$. $\mathrm{N}$ addition exhibited a slight increase in the sensitivity of $R \mathrm{~s}$ to temperature $\left(Q_{10}\right)$, but no significant differences were found for the $Q_{10}$ among $\mathrm{N}$ levels.
\end{abstract}

Keywords: nitrogen supply, soil respiration, sample interval, $Q_{10}$ Larix principis-rupprechtii

\section{Introduction}

Atmospheric nitrogen $(\mathrm{N})$ deposition has already increased by three- to five-fold over the past century due to fossil fuel combustion, fertilizer production, and cultivation [1]. $\mathrm{N}$ deposition is predicted to increase in many parts of the world in the next decades because of the rapid development and expansion of industrial and agricultural activities and thus has been considered a major scientific challenge [2]. The evidence is mounting that increased $\mathrm{N}$ deposition has inevitably altered regional and global environments and

*e-mail: hanhr@bjfu.edu.cn has affected the carbon (C) cycle of terrestrial ecosystems [3-4].

Soil respiration $(R \mathrm{~s})$ is one of the largest sources of carbon dioxide $\left(\mathrm{CO}_{2}\right)$ returning from soil to the atmosphere $[3,5]$. Global $\mathrm{CO}_{2}$ flux through soil respiration is approximately $80-98 \mathrm{Pg} \mathrm{C} \mathrm{yr}^{-1}$ [6], and annual $\mathrm{CO}_{2}$ efflux from soil respiration is about 10 times the annual $\mathrm{CO}_{2}$ emissions from burning fossil fuels [7]. Thus, knowledge of the response of $R \mathrm{~s}$ to $\mathrm{N}$ deposition is important for improving our ability in modeling the terrestrial $\mathrm{C}$ cycle [8]. However, the effect of $\mathrm{N}$ addition on $R \mathrm{~s}$ remains inconsistent for results from field observations [9], models [10], and meta-analyses [11], including stimulation [1213], inhibition [14], and no change [15]. This inconsistency is largely related to differences in biome types, $\mathrm{N}$ addition rates, soil conditions, and even experimental 
methods [16-17], The underlying mechanisms for these disagreements, however, are still unclear and need to be further investigated. The diverse responses of $R \mathrm{~s}$ to $\mathrm{N}$ addition indicates that more observations are required to understand regulatory mechanisms of $\mathrm{N}$ addition to the key $\mathrm{C}$ process in terrestrial ecosystems.

Numerous studies have investigated the effect of $\mathrm{N}$ addition on Rs. Generally, a large number of field and laboratory studies have examined the effect of $\mathrm{N}$ addition on $R \mathrm{~s}$ by periodic measurements of the respiratory processes. Measurements of $R \mathrm{~s}$ after $\mathrm{N}$ addition varied across studies, and the majority of sample interval from one week to one month after $\mathrm{N}$ addition [18-20]. However, an examination of how sampling interval affects $R \mathrm{~s}$ and investigation into the duration of this effect after $\mathrm{N}$ addition received little attention. $\mathrm{N}$ addition would have a pulse effect on $R \mathrm{~s}$ in a short time after $\mathrm{N}$ application. Currently, the duration of this effect after $\mathrm{N}$ addition is still not well known. Resolution of this question would be helpful for providing an explanation as to why $R$ s varies so much in response to $\mathrm{N}$ addition.

We used a long-term $\mathrm{N}$ addition experiment to assess $R$ s continuously and frequently after $\mathrm{N}$ application during the growing season in a larch (Larix principis-rupprechtii) plantation. Our main objectives were: a) to explore the variations in the response of $R \mathrm{~s}$ to $\mathrm{N}$ addition, $\mathrm{b}$ ) to determine the duration of $\mathrm{N}$ addition effect on $R \mathrm{~s}$ after $\mathrm{N}$ application, and c) to investigate the driving factors that regulate the response of $R \mathrm{~s}$ to $\mathrm{N}$ addition.

\section{Materials and Methods}

\section{Study Site}

Our study site was located in Haodifang forestry $\left(36^{\circ} 47^{\prime} 04^{\prime \prime} \mathrm{N}\right.$ and $112^{\circ} 00^{\prime} 57^{\prime \prime} \mathrm{E}$; $2276 \mathrm{~m}$ a.s.1.) in Shanxi Province in northern China. This region was classified as a warm-temperate semi-arid continental, mountainous climate affected by monsoons, with a mean annual temperature of $6.2^{\circ} \mathrm{C}$. The highest monthly average temperature of $22.4^{\circ} \mathrm{C}$ occurred in July, whereas the lowest monthly average temperature of $-4.6^{\circ} \mathrm{C}$ occurred in January. Mean annual precipitation was $770 \mathrm{~mm}$ with

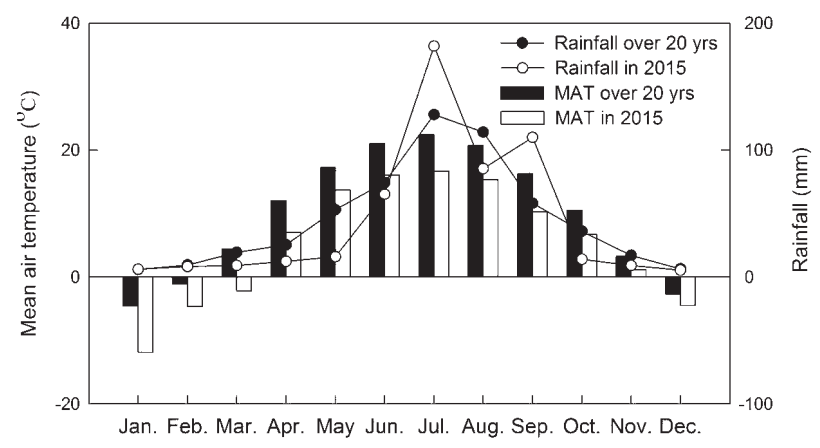

Fig. 1. Mean air temperature and rainfall during the last 20 years and in 2015. an average relative humidity of $65 \%$. Over a year, the distribution of precipitation was relatively uneven. The wet season was from June to September, which accounted for more than $70 \%$ of annual precipitation (Fig. 1). Soils are developed from well-weathered rocks and are classified as a haplic luvisols (according to the FAO soil taxonomy), and it has an average depth of $60 \mathrm{~cm}$. The soil organic matter content ranges from 1 to $4 \% \mathrm{w} / \mathrm{w}$.

The study site was a pure plantation of Larix principisrupprechtii, established with 5-year-old seedlings in 1980 at a stocking density of 1,000 stems per ha. The density of the forest now is $618 \mathrm{stems} / \mathrm{ha}$ with a total basal area of $5.68 \mathrm{~m}^{2} /$ ha. The mean height of overstory was $22.5 \mathrm{~m}$ with a mean breast-height diameter of $18.6 \mathrm{~cm}$. The understory trees were primarily Spiraea salicifolia, Lespedeza bicolor, Corylus mandshurica, and Rosa xanthina. The mean height of the understory was $1.8 \mathrm{~m}$ with a mean breast-height diameter of $2.0 \mathrm{~cm}$. Carex tristachya and various other species of the family Cyperaceae were common herbs.

\section{Experimental Design}

At the study site, we established a random block design with three blocks as replicates. In each block, we randomly established $2 \times 2 \mathrm{~m}$ plots $(4 \mathrm{~N}$ addition treatments $\times 3$ replicates $=12$ plots) in April 2015. Each plot in a block was surrounded by a 2-m wide buffer strip. Each block was then assigned randomly to one of the four $\mathrm{N}$ treatment levels: control (N0), low-N (N1), medium-N (N2), and high-N (N3). In each plot, PVC collars $(20 \mathrm{~cm}$ in diameter and $10 \mathrm{~cm}$ in height) were placed and inserted 5-6 cm into the soil for measurement of soil respiration $(R \mathrm{~s})$. The location of the collars did not change during $R s$ measurements.

The first $\mathrm{N}$ addition was applied on 31 May 2015. Nitrogen was added in the form of ammonium nitrate $\left(\mathrm{NH}_{4} \mathrm{NO}_{3}, \mathrm{AR}\right)$ in water at the rate of $5 \mathrm{~g} \mathrm{~N} \mathrm{~m}^{-2}$ year ${ }^{-1}$, $10 \mathrm{~g} \mathrm{~N} \mathrm{~m}^{-2}$ year ${ }^{-1}$, and $15 \mathrm{~g} \mathrm{~N} \mathrm{~m}^{-2}$ year ${ }^{-1}$ in $\mathrm{N} 1, \mathrm{~N} 2$, and $\mathrm{N} 3$ treatments, respectively. In each plot, the fertilizer was weighed, mixed with five litres of water, and sprayed to the plots using a portable sprayer at the end of each month from June to September. The N0 plots received five litres of water without fertilizer.

\section{Soil Respiration and Microclimate}

Soil respiration measurements were initiated 24 hours after the installing the collars. The $R \mathrm{~s}$ was measured after each $\mathrm{N}$ addition application from June to September in 2015. We measured $R \mathrm{~s}$ using an automated soil $\mathrm{CO}_{2}$ flux system (LI-8100, LI-COR, Nebraska, USA) from 08:00 to 18:00 h, the $R$ s was monitored three consecutive days after each $\mathrm{N}$ addition application and measured 3-5 times in the remaining days of each month. The rates for each $\mathrm{N}$ treatment were averaged for the following data analysis.

The cumulative soil $\mathrm{CO}_{2}$ efflux from the plots was calculated as the mean of the cumulative $\mathrm{CO}_{2}$ effluxes of 
the three replicates for each $\mathrm{N}$ treatment. Accumulative daily mean soil respiration efflux was calculated as follows:

$$
D R s=(R s \times 24 \times 3600 \times 12) \times 10^{-6}
$$

...where $D R \mathrm{~s}$ is the accumulative daily means soil respiration $\left(\mathrm{g} \mathrm{C}^{-2} \mathrm{~m}^{-2}\right), R \mathrm{~s}$ is the daily mean soil respiration rate $\left(\mu \mathrm{mol} \cdot \mathrm{m}^{-2} \cdot \mathrm{s}^{-1}\right)$ in each plot, 24 is the number of hours per day, 3,600 the number of seconds per hour, and 12 represents the molar mass of carbon.

Soil temperature $(S T)$ at $10 \mathrm{~cm}$ depth were measured adjacent to each $R \mathrm{~s}$ collar with a portable temperature probe provided with the LI-8100 system simultaneously with each $R s$ measurement. Soil moisture $(S W)$ at $10 \mathrm{~cm}$ was measured using a moisture probe (Delta-T Devices, Cambridge, UK) at three points close to each collar for each $R s$ measurement.

\section{Soil Properties and Microbial Biomass}

Before the first $\mathrm{N}$ addition application, five soil samples were collected from the top $20 \mathrm{~cm}$ of the mineral soil next to each collar using 100-ml sampling cylinders in May 2015. We mixed five soil samples for soil bulk density, $\mathrm{pH}$, soil organic carbon (SOC), total $\mathrm{N}(\mathrm{TN})$, total $\mathrm{P}$ (TP), and total K (TK) measurement. The combined samples were passed through a $2 \mathrm{~mm}$ sieve to remove roots and coarse fragments for further analysis. Soil $\mathrm{pH}$ was measured with a glass electrode in a 1:2 soil-to-water ratio. TN was determined by Kjeldahl digestion with a salicylic acid modification [21]; soil bulk density, TP, and TK were measured using standard methods [22]; and SOC using the method described by Kalembasa and Jenkinson [23]. Table 1 shows detailed soil properties for each $\mathrm{N}$ addition plot.

Three soil cores $(10 \mathrm{~cm}$ in depth and $2.5 \mathrm{~cm}$ in diameter) were randomly collected from the top $10 \mathrm{~cm}$ soil from each plot in October 2015 at the end of the growing season and mixed to form a composite sample. After removing roots and plant residues, these composite samples were immediately sieved through a $2 \mathrm{~mm}$ mesh sieve in the field and refrigerated. Soil microbial biomass carbon (MBC) and microbial biomass nitrogen (MBN) were measured using the chloroform direct-fumigation extraction method [24].

\section{Modeling $R s$ with $S T$ and $S W$}

The univariate and bivariate models were used to describe the relationships between $R \mathrm{~s}$ and $S T$ and $S W$ [25]. The first model shows $R s$ as an exponential function with only ST (ST model) as the variable (Eq. (2)), while temperature sensitivity $\left(Q_{10}\right)$ was calculated using Eq. (3):

$$
\begin{aligned}
& R S=\beta_{0} e^{\beta 1 S T} \\
& Q_{10}=\mathrm{e}^{10 \beta 1}
\end{aligned}
$$

...where $R \mathrm{~s}\left(\mu \mathrm{mol} \mathrm{m} \mathrm{m}^{-2} \mathrm{~s}^{-1}\right)$ is soil respiration, $S T\left({ }^{\circ} \mathrm{C}\right)$ is soil temperature at $10 \mathrm{~cm}$ depth, and $\beta_{0}$ and $\beta_{1}$ are model parameters.

The quadratic model was used to describe the relationship between $R$ s and $S W$ ( $S W$ model) (Eq. (4)):

$$
R s=\beta_{2}+\beta_{3} S M+\beta_{4} S M^{2}
$$

...where $S M(\%)$ is soil moisture at $10 \mathrm{~cm}$ depth and $\beta_{2}, \beta_{3}$, and $\beta_{4}$ are model parameters.

A bivariate model was used to explore the relationship between $R$ s soil temperature $(S T)$ and soil moisture $(S W)$ (ST\&SW model) (Eq. (5)):

$$
R S=\beta_{5} e^{\beta 6 S T} S M^{\beta 7}
$$

$\ldots$ where $\beta_{5}, \beta_{6}$, and $\beta_{7}$ are model parameters.

\section{Statistical Analyses}

A two-way analysis of variance was used to investigate the effects of month $(M)$ and $\mathrm{N}$ treatment level $(N)$ on soil temperature, soil moisture, and $R \mathrm{~s}$. For each month, repeated-measurement analyses of variance were applied to assess the effects of sample date $(D)$ and $\mathrm{N}$ treatment level $(N)$ on soil temperature, soil moisture, and $R$ s. One-way analysis of variance was applied to test the effect of $\mathrm{N}$ addition on soil properties and soil microbial biomass. The significance level was set at $0.05(p<0.05)$, and all statistical tests were performed using SPSS (ver. 16.0) and R3.3.2 (www.R-project.org).

Table 1. Soil properties to a depth of $20 \mathrm{~cm}$ in each plot of $\mathrm{N}$ addition treatment.

\begin{tabular}{|c|c|c|c|c|c|c|}
\hline Treatment & $\begin{array}{c}\text { Bulk density } \\
\left(\mathrm{g} \mathrm{cm}^{-3}\right)\end{array}$ & $\mathrm{pH}$ & $\begin{array}{c}\text { Soil organic carbon } \\
\left(\mathrm{g} \mathrm{kg}^{-1}\right)\end{array}$ & $\begin{array}{c}\text { Total N } \\
\left(\mathrm{g} \mathrm{kg}^{-1}\right)\end{array}$ & $\begin{array}{c}\text { Total P } \\
\left(\mathrm{g} \mathrm{kg}^{-1}\right)\end{array}$ & $\begin{array}{c}\text { Total K } \\
\left(\mathrm{g} \mathrm{kg}^{-1}\right)\end{array}$ \\
\hline $\mathrm{N} 0$ & $0.96 \pm 0.04 \mathrm{a}$ & $7.6 \pm 0.1 \mathrm{a}$ & $20.0 \pm 0.04 \mathrm{a}$ & $2.32 \pm 0.03 \mathrm{a}$ & $0.54 \pm 0.02 \mathrm{a}$ & $14.9 \pm 0.0 \mathrm{a}$ \\
\hline $\mathrm{N} 1$ & $1.12 \pm 0.09 \mathrm{~b}$ & $7.7 \pm 0.1 \mathrm{a}$ & $19.8 \pm 0.1 \mathrm{a}$ & $2.35 \pm 0.02 \mathrm{a}$ & $0.53 \pm 0.01 \mathrm{a}$ & $15.6 \pm 0.0 \mathrm{ab}$ \\
\hline $\mathrm{N} 2$ & $1.15 \pm 0.05 \mathrm{~b}$ & $7.7 \pm 0.1 \mathrm{a}$ & $19.9 \pm 0.1 \mathrm{a}$ & $2.38 \pm 0.03 \mathrm{a}$ & $0.58 \pm 0.02 \mathrm{a}$ & $15.48 \pm 0.0 \mathrm{ab}$ \\
\hline $\mathrm{N} 3$ & $1.10 \pm 0.07 \mathrm{~b}$ & $7.7 \pm 0.1 \mathrm{a}$ & $20.0 \pm 0.1 \mathrm{a}$ & $2.47 \pm 0.04 \mathrm{a}$ & $0.66 \pm 0.03 \mathrm{~b}$ & $16.1 \pm 0.1 \mathrm{~b}$ \\
\hline
\end{tabular}

Data are means \pm S.E. Different letters at the same column represent significant differences at $p<0.05$. 
Table 2. Results ( $F$-values) of two-way ANOVA for soil temperature and soil moisture at $10 \mathrm{~cm}$ depth, and soil respiration rate from June to September 2015 .

\begin{tabular}{|c|c|c|c|}
\hline Source of variation & $\begin{array}{c}\text { Soil temperature } \\
\text { at } 10 \mathrm{~cm} \text { depth }\end{array}$ & $\begin{array}{c}\text { Soil moisture } \\
\text { at } 10 \mathrm{~cm} \text { depth }\end{array}$ & Soil respiration rate \\
\hline Month $(M)$ & $4416^{* * *}$ & $12.18^{* * *}$ & $10.13^{* * *}$ \\
\hline $\mathrm{N}$ treatment level $(N)$ & 0.58 & 0.86 & $2.22^{* * *}$ \\
\hline$N \times M$ & 0.34 & 0.06 & 0.05 \\
\hline
\end{tabular}

${ }^{* * *} p<0.001$

\section{Results}

\section{Soil Temperature and Soil Moisture}

The ANOVA showed that soil temperature and soil moisture had significant monthly variation (Table 2). The highest temperature was in July and the lowest in September, and the highest moisture was observed in August and the lowest in June. $\mathrm{N}$ addition appeared to have no significant effects on soil temperature and soil moisture $(p>0.05)$, although both had significant intermonthly variations (Table 3 ).

\section{Seasonal Variation of Rs}

$R$ s showed a distinct seasonality, with the highest value observed in August and the lowest observed in September (Table 1, Fig. 2). The average rate of $R \mathrm{~s}$ was $3.00 \mu \mathrm{mol} \mathrm{m} \mathrm{m}^{-2} \mathrm{~s}^{-1}$ in June. The respective values were $3.86 \mu \mathrm{mol} \mathrm{m} \mathrm{m}^{-2} \mathrm{~s}^{-1}$ in July, $4.38 \mu \mathrm{mol} \mathrm{m} \mathrm{m}^{-2} \mathrm{~s}^{-1}$ in August, and $2.09 \mu \mathrm{mol} \mathrm{m} \mathrm{m}^{-2} \mathrm{~s}^{-1}$ in September. During the entire observation period, the average $R \mathrm{~s}$ rate was $3.33 \mu \mathrm{mol} \mathrm{m} \mathrm{m}^{-2} \mathrm{~s}^{-1}$ irrespective of the $\mathrm{N}$ addition effect.

$\mathrm{N}$ addition significantly increased $R \mathrm{~s}(p<0.05)$, and the rate increased with the level of $\mathrm{N}$ addition. The average rate of $R \mathrm{~s}$ at the N0, N1, N2, and $\mathrm{N} 3$ level was 2.61, 2.79, 3.30 , and $4.47 \mu \mathrm{mol} \mathrm{m}^{-2} \mathrm{~s}^{-1}$, respectively.

$R$ s increased with $\mathrm{N}$ levels after $\mathrm{N}$ addition in each month (Fig. 2). $\mathrm{N}$ addition showed a strong stimulatory effect on $R \mathrm{~s}$ during the first 1-3 days. After this, the stimulatory effect at the N1 and N2 levels weakened. However, at the $\mathrm{N} 3$ level, $\mathrm{N}$ addition presented the stimulatory effect across the whole month in June, July,

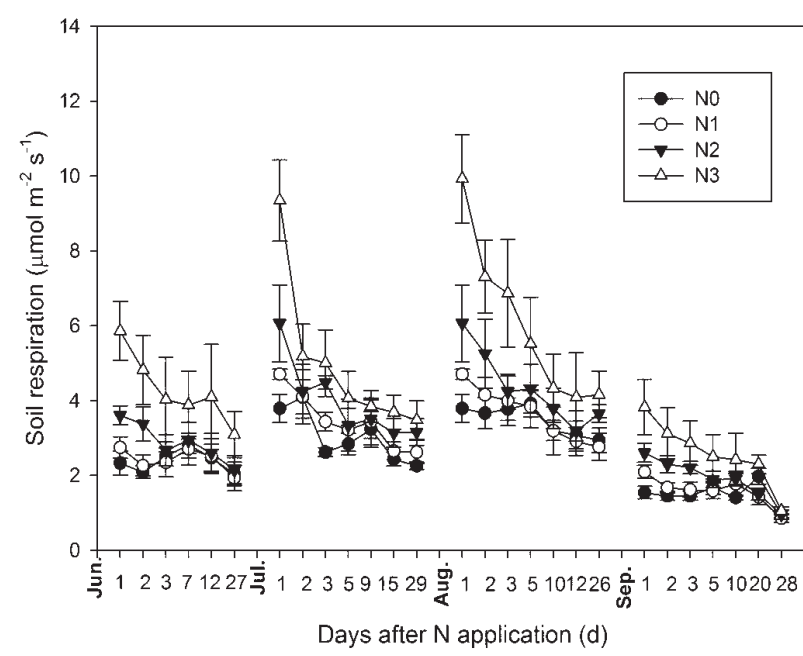

Fig. 2. Seasonal dynamics of $R \mathrm{~s}$ among $\mathrm{N}$ treatment levels. Error bars are \pm S.E.

and August, and this effect lasted at least 10 days into September.

\section{Cumulative $R$ s Among N Treatment Levels}

The cumulative $R \mathrm{~s}$ increased with $\mathrm{N}$ levels after $\mathrm{N}$ addition in each month (Fig. 3). During the entire study period, the N2 and N3 levels significantly stimulated the cumulative $R \mathrm{~s}(p<0.05)$. By the end of our study, the cumulative $R$ s increased by $2.10 \%, 16.19 \%$, and $51.75 \%$ at the N1, N2, and N3 levels, respectively, relative to the cumulative $R \mathrm{~s}$ at the N0 level.

Table 3. Results ( $F$-values) of repeated measures for soil temperature and soil moisture at $10 \mathrm{~cm}$ depth and soil respiration rate in June, July, August, and September 2015. Date is the sampling date within each month.

\begin{tabular}{|c|c|c|c|c|c|c|c|c|c|c|c|c|}
\hline \multirow{2}{*}{$\begin{array}{c}\text { Source of } \\
\text { variation }\end{array}$} & \multicolumn{2}{|c|}{ Soil temperature at $10 \mathrm{~cm}$ depth $(S T)$} & \multicolumn{2}{|c|}{ Soil moisture at $10 \mathrm{~cm}$ depth $(S W)$} & \multicolumn{5}{|c|}{ Soil respiration rate $(R \mathrm{~s})$} \\
\cline { 2 - 15 } & June & July & August & September & June & July & August & September & June & July & August & September \\
\hline Date $(D)$ & $212.3^{* * *}$ & $1234^{* * *}$ & $480.9^{* * *}$ & $1707^{* * *}$ & $201.20^{* * *}$ & $20.02^{* * *}$ & $8.67^{* * *}$ & $9.12^{* * *}$ & $30.09^{* * * *}$ & $81.90^{* * *}$ & $16.34^{* * *}$ & $101.39^{* * *}$ \\
\hline $\begin{array}{c}\text { N treatment } \\
\text { level }(N)\end{array}$ & 0.439 & 0.48 & 0.28 & 0.658 & 2.02 & 2.77 & 1.18 & 1.30 & 2.06 & $1.45^{*}$ & 1.36 & $6.21^{* * *}$ \\
\hline$D \times N$ & 0.35 & 1.18 & 1.04 & 0.60 & 0.83 & 0.95 & 0.71 & 0.88 & $2.51^{*}$ & $8.49^{* * *}$ & $4.90^{* * *}$ & $4.54^{* *}$ \\
\hline
\end{tabular}

${ }^{* * *} p<0.001,{ }^{* *} p<0.01,{ }^{*} p<0.05$ 


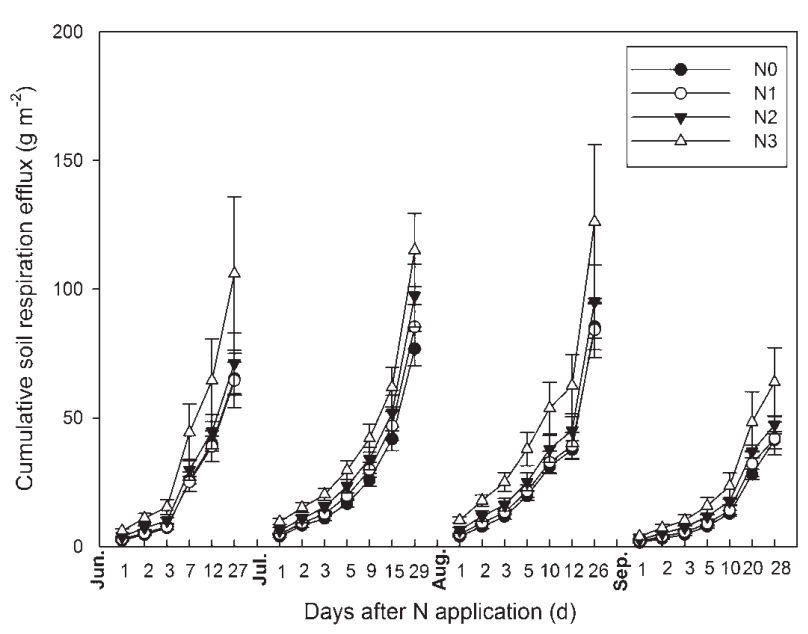

Fig. 3. Cumulative Rs efflux at different $\mathrm{N}$ treatment levels.

\section{Relationships between $R$ s and $S T$ and $S W$}

Soil respiration significantly correlated with soil temperature in the four $\mathrm{N}$ treatments during the entire observation period $(p<0.001$, Fig. 4). Soil temperature explained $39.0-69.4 \%$ of the seasonal variation in $R$ s over the sampling period. The strongest relationship between $R \mathrm{~s}$ and soil temperature was found in N1 (Table 4). Estimates of the model parameter $\left(\beta_{1}\right)$ showed that the relationship between $R \mathrm{~s}$ and soil temperature was not affected by $\mathrm{N}$ addition. Although temperature sensitivity $\left(Q_{10}\right)$ increased in the order of $\mathrm{N} 0<\mathrm{N} 3<\mathrm{N} 2<\mathrm{N} 1$, no significant differences were found for the $Q_{10}$ among $\mathrm{N}$ treatments $(p>0.05)$.

There was a significant correlation between $R \mathrm{~s}$ and soil moisture in the four $\mathrm{N}$ treatments over the sampling period $(p<0.05$, Table 3$)$. Soil moisture explained $22.3-36.4 \%$ of the seasonal variation in the $R \mathrm{~s}$.

$S T \& S W$ model predicted $R \mathrm{~s}$ rather well, and $R \mathrm{~s}$ was highly dependent on the combined effects of soil temperature and soil moisture (Table 4). The ST\&SW model for temperature and moisture explained $72.4 \%$, $76.2 \%, 70.3 \%$, and $51.8 \%$ of the variations in $R$ s for N0, $\mathrm{N} 1, \mathrm{~N} 2$, and $\mathrm{N} 3$ treatments, respectively. $R \mathrm{~s}$ in the N0 plots had the same sensitivity to soil temperature and soil moisture, whereas $R \mathrm{~s}$ in the $\mathrm{N} 1, \mathrm{~N} 2$, and N3 plots was more responsive to soil temperature (Fig. 5).
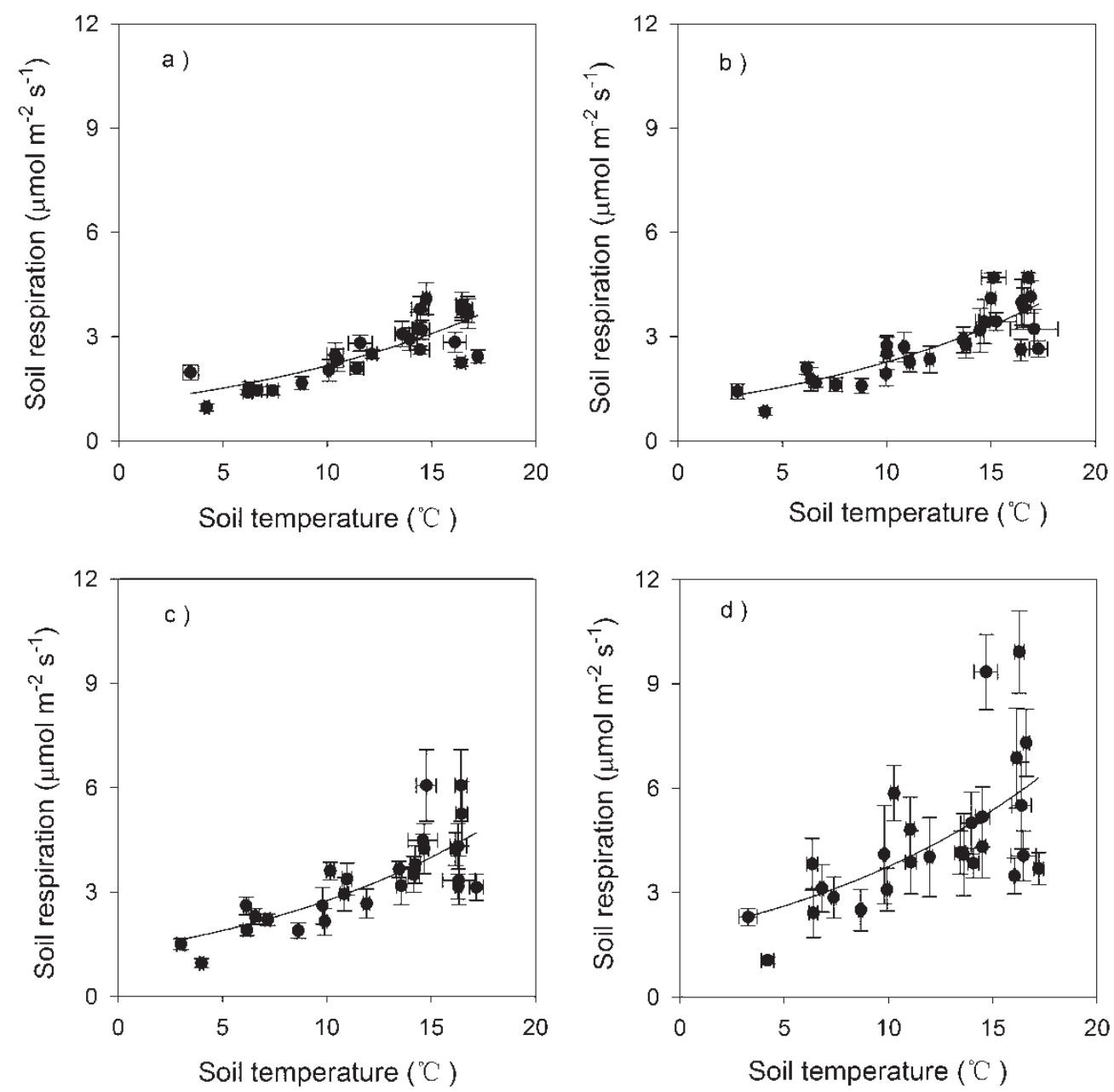

Fig. 4. Relationship between $R \mathrm{~s}$ and soil temperature at $10 \mathrm{~cm}$ depth in control (a), low-N (b), medium-N (c), and high-N (d) during observational period (June-September 2015). Points are daily means \pm S.E. The fit of the $S T$ model (Eq. (2)) is given in Table 4. 
Table 4. Parameters of different models of $R s$ as a function of $S T$ and $S W$. Data are mean \pm S.E

\begin{tabular}{|c|c|c|c|c|c|}
\hline N treatment & \multicolumn{3}{|c|}{ Parameters } & $R_{10}$ \\
\hline$S T$ model & $\beta_{0}$ & $\beta_{1}$ & $p$ & 0.662 & 2.03 \\
\hline N0 & $1.074 \pm 0.178$ & $0.071 \pm 0.012$ & $<0.001$ & 0.694 & 2.14 \\
\hline N1 & $1.070 \pm 0.183$ & $0.076 \pm 0.012$ & $<0.001$ & 0.602 & 2.12 \\
\hline N2 & $1.304 \pm 0.264$ & $0.075 \pm 0.014$ & $<0.001$ & 0.390 & 2.05 \\
\hline N3 & $1.826 \pm 0.537$ & $0.072 \pm 0.021$ & $<0.001$ & $p$ & $R^{2}$ \\
\hline$S W$ model & $\beta_{2}$ & $\beta_{3}$ & $\beta_{4}$ & $<0.01$ & 0.364 \\
\hline N0 & $8.623 \pm 3.126$ & $-0.489 \pm 0.205$ & $0.009 \pm 0.003$ & $<0.01$ & 0.323 \\
\hline N1 & $19.481 \pm 7.479$ & $-1.155 \pm 0.465$ & $0.019 \pm 0.007$ & $<0.05$ & 0.223 \\
\hline N2 & $21.125 \pm 10.676$ & $-1.196 \pm 0.647$ & $0.019 \pm 0.010$ & $<0.001$ & 0.318 \\
\hline N3 & $26.436 \pm 8.509$ & $-1.628 \pm 0.569$ & $0.028 \pm 0.009$ & $p$ & $R^{2}$ \\
\hline$S T \& S W$ model & $\beta_{5}$ & $\beta_{6}$ & $\beta_{7}$ & $<.01$ \\
\hline N0 & $0.857 \pm 0.243$ & $0.074 \pm 0.010$ & $0.004 \pm 0.007$ & $<0.001$ & 0.724 \\
\hline N1 & $0.924 \pm 0.328$ & $0.081 \pm 0.010$ & $0.002 \pm 0.009$ & $<0.001$ & 0.762 \\
\hline N2 & $1.112 \pm 0.363$ & $0.082 \pm 0.016$ & $0.001 \pm 0.010$ & $<0.001$ & 0.703 \\
\hline N3 & $1.687 \pm 0.407$ & $0.080 \pm 0.017$ & $-0.002 \pm 0.012$ & $<0.001$ & 0.518 \\
\hline
\end{tabular}

\section{Soil Microbial Biomass}

The variations in $\mathrm{MBC}, \mathrm{MBN}$, and the $\mathrm{MBC} / \mathrm{MBN}$ ratios at different $\mathrm{N}$ levels are shown in Fig. 6. The MBC and MBN increased with $\mathrm{N}$ levels. The MBC values at the
$\mathrm{N} 3$ level were significantly higher than the values at the $\mathrm{N} 0$ level $(p<0.05)$. The MBC at the N1, N2, and N3 levels increased by $13.4 \%, 37.0 \%$, and $64.3 \%$, respectively, relative to the N0 level. No significant differences were found in the MBN among $\mathrm{N}$ levels $(p>0.05)$. The
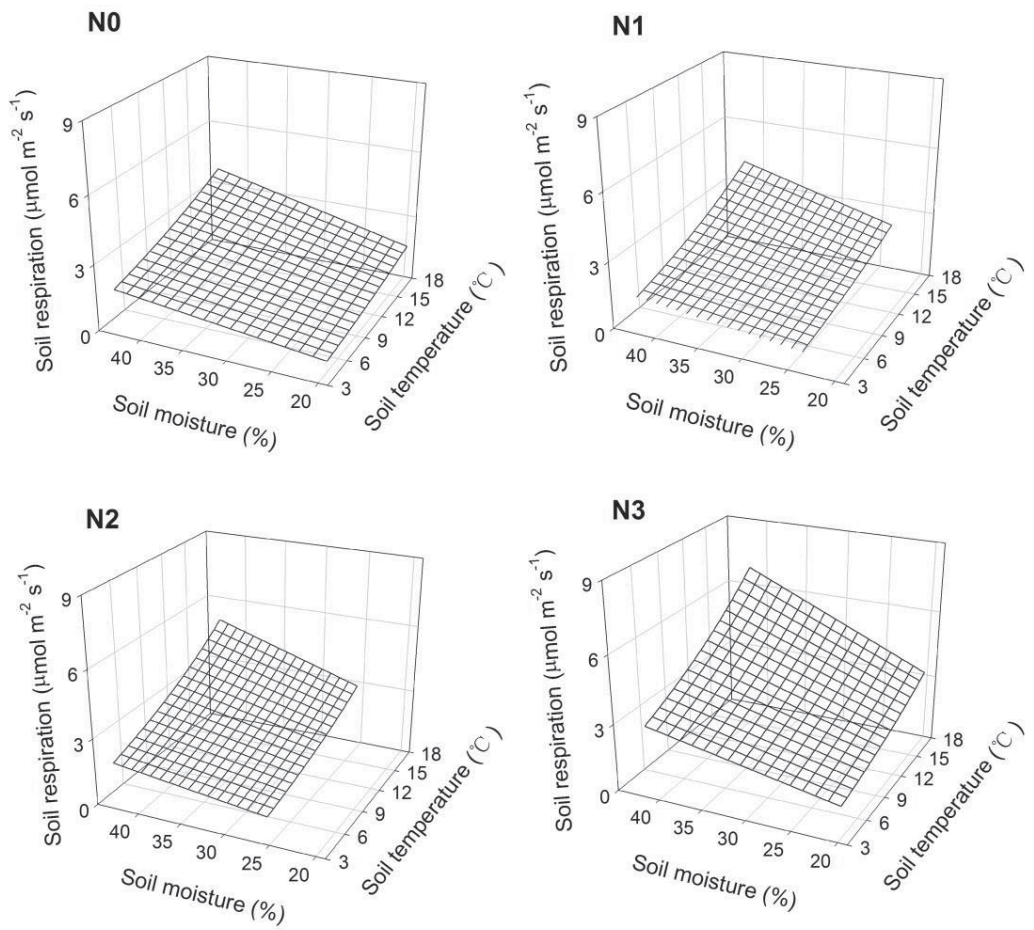

Fig. 5. 3D images of soil respiration models for N treatments with soil temperature and soil moisture. The mesh is fitted using the $S T \&$ $S W$ model in Table 4. 


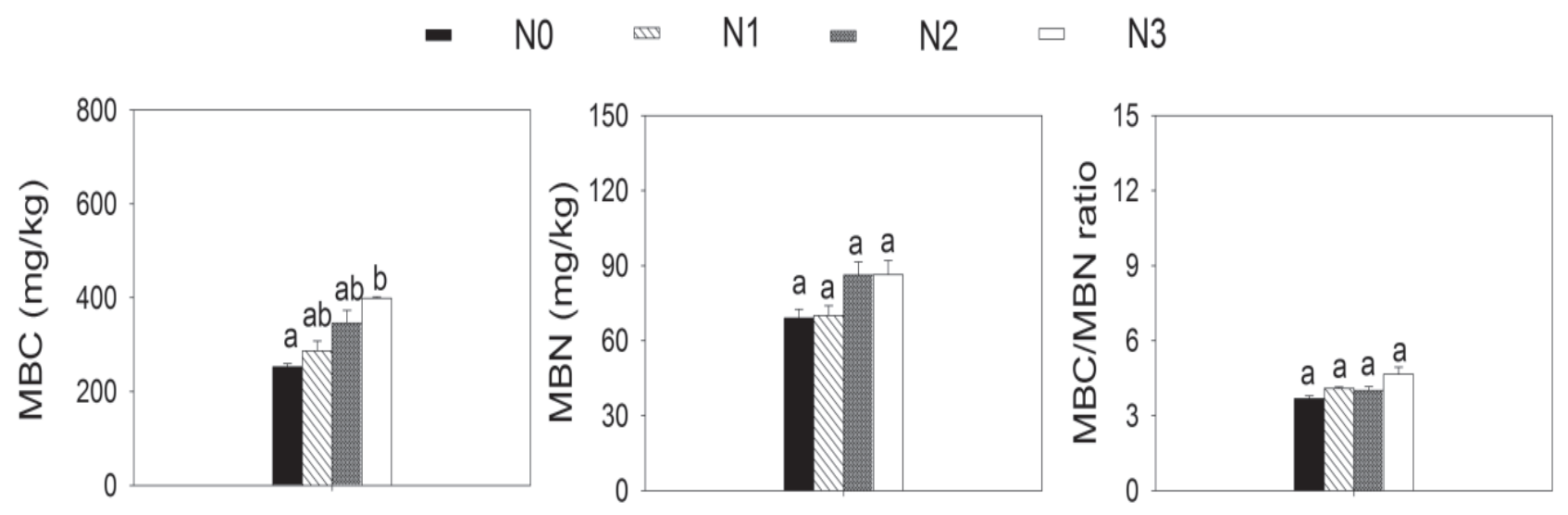

Fig. 6. Dynamics of soil microbial C (MBC), microbial N (MBN), and the MBC/MBN ratio at different $\mathrm{N}$ treatment levels.

$\mathrm{MBC} / \mathrm{MBN}$ ratio at the N0, N1, N2, and N3 levels was $3.68,4.09,4.01$, and 4.86, respectively. No significant differences were found for the $\mathrm{MBC} / \mathrm{MBN}$ ratio among $\mathrm{N}$ levels $(p>0.05)$.

\section{Discussion}

\section{Effect of Nitrogen Addition on Phytoclimate and Soil Respiration}

A previous study has shown that increased plant growth and productivity under fertilization can result in shadowing, and thus a decrease in soil temperature in a temperate steppe [26]. Furthermore, a previous study also found that $\mathrm{N}$-induced plant growth can result in higher evapotranspiration and more depletion of soil water content in grassland [27]. However, $\mathrm{N}$ addition appeared to have no significant effects on soil temperature and moisture in our study, which is consistent with results reported in a mature tropical forest [14]. This could be ascribed to the fact that forest canopy closure did not change throughout the whole observation period and the forest canopy could mediate the response of soil environment to $\mathrm{N}$ addition [28]. A number of studies have reported that $\mathrm{N}$ addition has both increased [29] and decreased $R$ s [30-31]. These inconsistent results could be largely due to the differential responses of two soil components: autotrophic respiration $(R a)$ and heterotrophic respiration $(R \mathrm{~h})$. The individual response of each component to $\mathrm{N}$ addition determined the direction of the total $R$ s response [32]. $\mathrm{N}$ addition in the present study resulted in an increase in the $R \mathrm{~s}$ throughout the observation period, similar to the results of previous studies in different ecosystems [29, 33-34]. The effect of $\mathrm{N}$ addition on the $R$ s was suggested to correlate with soil background $\mathrm{N}$ level of studied forest. Due to $\mathrm{N}$ deficiency in such a young forest, external $\mathrm{N}$ addition could either enhance $\mathrm{N}$ immobilization of the microbes or improve $\mathrm{N}$ absorption of the roots [29]. The stimulation of $R \mathrm{~s}$ by $\mathrm{N}$ addition has been explained by $\mathrm{N}$-induced increases in $\mathrm{C}$ substrate for root and fine root biomass, and $R$ s generally has a positive correlation with the fine root biomass due to respiration from coarse root being relatively low [35]. Therefore, we speculated that $\mathrm{N}$ addition stimulated $R$ a via increasing the fine root biomass or respiration of autotrophic bacteria by root exudates [36].

Soil $R \mathrm{~h}$ is another part of $R \mathrm{~s}$ and is derived from the decomposition of aboveground litter and soil organic matter [11]. Aboveground litter respiration is dependent on the accumulated litter layers and the rate of litter decomposition. Higher net primary productivity under fertilization leads to more labile $\mathrm{C}$ substrate inputs into the soil through litterfall [37]. Fresh $\mathrm{C}$ input provides more energy to sustain the activity of microorganisms, which is typically C-limited, and thus accelerates the decomposition of recalcitrant soil organic matter and subsequently increases $R \mathrm{~s}$ [38]. We found that the aboveground litterfall in the study area increased significantly [39]. Similarly, Li et al. [40] studied C cycling in a tropical rain forest in Puerto Rico and found that seven years of continual fertilization increased aboveground litterfall production and stimulated litter decomposition. Magill et al. [41] found that 15 years of chronic $\mathrm{N}$ additions increased aboveground litterfall in a red pine (Pinus resinosa) plantation. A number of other studies also reported that experimental $\mathrm{N}$ addition increased aboveground litter decomposition by increasing litter substrate quality, which also enhanced soil microbial activities [42-43]. Therefore, the increased $\mathrm{CO}_{2}$ efflux from the decomposition of aboveground litter and soil organic carbon under $\mathrm{N}$ addition was likely caused by $\mathrm{N}$-induced increasing aboveground litter input, stimulating the rate of litter decomposition and enhancing soil microbial activity in the early stage of decomposition [44]. Some previous studies also have reported that $\mathrm{N}$ addition would inhibit $R \mathrm{~s}$ by decreasing fine root biomass, litter decomposition rate, and microbial activity when the ecosystem is subjected to long-term $\mathrm{N}$ addition and $\mathrm{N}$ supply exceeds plant needs. Further investigations, therefore, are needed to explore the long-term response of $R \mathrm{~s}$ to $\mathrm{N}$ addition in the studied forest. This could be helpful for enhancing our understanding of climate-C feedback of this ecosystem.

We found that the magnitude of $\mathrm{N}$ addition effect was seasonal, with the largest effect occurring during 
June-August, which is consistent with results reported in a Chinese pine forest [45]. The duration of $\mathrm{N}$ addition effect was diverse among $\mathrm{N}$ levels. $\mathrm{N}$ addition presented a strong stimulatory effect on the $R \mathrm{~s}$ during the first 1-3 days. After this, the stimulatory effect at the N1 and N2 levels weakened. However, at the N3 level, N addition presented the strong stimulatory effect across the whole month in June, July, and August, and this effect can last at least 10 days into September. The mechanism for explaining these results might be related to the buffering aboveground litter layer and slow release of nutrients from decomposing litter added to the $\mathrm{N}$ addition effect.

\section{Soil Respiration in Relation to Soil Temperature and Moisture}

Soil temperature and soil moisture have been reported to directly alter the activities of plant roots and soil microbes and indirectly affect pedofauna activity, and thus alter $R \mathrm{a}$ and $R \mathrm{~h}[39]$. In this study, we also found that $R \mathrm{~s}$ exhibited significant positive relationships with soil temperature, which is in agreement with results reported in temperate forests [29] and in grassland [32]. Our model showed that soil temperature was more closely correlated with $R \mathrm{~s}$ than was soil moisture, both in the $\mathrm{N}$ addition and the control plots. This finding is also compatible with other studies [46-47]. Indeed, soil temperature and soil moisture together have been shown to play a critical role in explaining more variations of $R \mathrm{~s}$ than the $S T$ or $S W$ models alone. The $Q_{10}$ value was 2.03 in the control plot, which is close to the median value reported in the review by Raich and Schlesinger [48], and lower than that of 3.9 in a temperate hardwood forest [49]. N addition led to a slight increase in $Q_{10}$ in the present study, although there were no significant differences in the $Q_{10}$ among treatments. It has been suggested that changes in the $Q_{10}$ by $\mathrm{N}$ addition result from concurrent variations in soil temperature and soil water content, which may affect root and microbial activities [50]. Thus, the non-significant differences in the $Q_{10}$ are largely attribute to the fact that there were no treatment effects on soil temperature and moisture by $\mathrm{N}$ addition.

\section{Conclusions}

Our data support that $\mathrm{N}$ addition stimulates soil respiration in an $\mathrm{N}$-limited plantation. In this study, increases in $R \mathrm{~s}$ depend on $\mathrm{N}$ addition levels. $\mathrm{N} 2$ and N3 levels significantly increased $R \mathrm{~s}$ in the view of seasonal cumulative flux. The duration of $\mathrm{N}$ addition effect was diverse among $\mathrm{N}$ levels. $\mathrm{N}$ addition showed a strong stimulatory effect on $R \mathrm{~s}$ during the first 1-3 days. After this, the stimulatory effect at the N1 and N2 levels weakened. However, N3 levels presented a strong stimulatory effect across the whole month or at least 10 days. This finding highlights the need to increase the frequency of $R \mathrm{~s}$ measurements to capture the real $R \mathrm{~s}$ responses to $\mathrm{N}$ addition. Increasing sampling frequency of $R \mathrm{~s}$ will help to understand why $R \mathrm{~s}$ varied so much to $\mathrm{N}$ addition and improve our ability in modeling $\mathrm{C}$ cycling in forest ecosystems. $R \mathrm{~s}$ was regulated by soil temperature and soil moisture and integrating soil temperature and soil moisture explained more variations of $R \mathrm{~s}$. We found that $\mathrm{N}$ addition did not change the sensitivity of $R \mathrm{~s}$ to temperature throughout the sampling period.

\section{Acknowledgements}

This research is supported by the National Key Research and Development Program of China (No. 2016YFD0600205), the National Forestry Public Welfare Professional Scientific Research Project (No. 201404213), and the CFERN and GENE Award Funds for Ecological Papers. The authors thank all those who provided helpful suggestions and critical comments on this manuscript including the anonymous reviewers. We also thank the Lingkong Mountain and Haodifang State Forest Farm for their support in fieldwork.

\section{References}

1. PINDER R.W., DAVIDSON E.A., GOODALE C.L., GREAVER T.L., HERRICK J.D., LIU L. Climate change impacts of US reactive nitrogen. P. Natl. Acad. Sci. USA. 109 (20), 7671, 2012.

2. GALLOWAY J.N., TOWNSEND A.R., ERISMAN J.W., BEKUNDA M., CAI Z., FRENEY J.R., MARTINELLI L.A., SEITZINGER S.P., SUTTON M.A. Transformation of the nitrogen cycle: recent trends, questions, and potential solutions. Science. 320 (5878), 889, 2008.

3. SCHLESINGER W.H., ANDREWS J.A. Soil respiration and the global carbon cycle. Biogeochemistry. 48 (1), 7, 2000.

4. REAY D.S., DENTENER F., SMITH P., GRACE J., FEELY R.A. Global nitrogen deposition and carbon sinks. Nat. Geosci. 1 (7), 430, 2008.

5. GAUMONT-GUAY D., BLACK T.A., MCCAUGHEY H., BARR A.G., KRISHNAN P., JASSAL R.S., NESIC Z. Soil $\mathrm{CO}_{2}$ efflux in contrasting boreal deciduous and coniferous stands and its contribution to the ecosystem carbon balance. Global Change Biol. 15 (5), 1302, 2009.

6. BOND-LAMBERTY B., BRONSON D., BLADYKA E., GOWER S.T. A comparison of trenched plot techniques for partitioning soil respiration. Soil Biol. Biochem. 43 (10), 2108, 2011.

7. BODEN T.A., MARLAND G., ANDRES R.J. Global, Regional, and National Fossil-fuel $\mathrm{CO}_{2}$ Emissions. In: Trends: a compendium of data on global change. Carbon Dioxide Information Analysis Center, Oak Ridge: Oak Ridge National Laboratory, U.S.A, 2009.

8. CHAPIN F.S., MCFARLAND J., MCGUIRE A.D., EUSKIRCHEN E.S., RUESS R.W., KIELLAND K. The changing global carbon cycle: linking plant-soil carbon dynamics to global consequences. J. Ecol. 97 (5), $840,2009$.

9. LIU L., HU C., YANG P., JU Z., OLESEN J.E., TANG J. Effects of experimental warming and nitrogen addition on soil respiration and $\mathrm{CH}_{4}$ fluxes from crop rotations of winter wheat-soybean/fallow. Agr. Forest Meteorol. 207, 38, 2015. 
10. DEVARAJU N., BALA G., CALDEIRA K., NEMANI R.A model based investigation of the relative importance of $\mathrm{CO}_{2}-$ fertilization, climate warming, nitrogen deposition and land use change on the global terrestrial carbon uptake in the historical period. Clim Dynam. 47, 173-190, 2016.

11. ZHOU L., ZHOU X., ZHANG B., LU M., LUO Y., LIU L., LI B. Different responses of soil respiration and its components to nitrogen addition among biomes: a metaanalysis. Global Change Biol. 20 (7), 2332, 2014.

12. MAGILL A.H., ABER J.D., HENDRICKS J.J., BOWDEN R.D., MELILLO J.M., STEUDLER P.A. Biogeochemical response of forest ecosystems to simulated chronic nitrogen deposition. Ecol. Appl. 7 (2), 402, 1997.

13. JANSSENS I., DIELEMAN W., LUYSSAERT S., SUBKE J., REICHSTEIN M., CEULEMANS R., CIAIS P., DOLMAN A., GRACE J., MATTEUCCI G., PAPALE D., PIAO S.L., SCHULZE E.D., TANG J., LAW B.E. Reduction of forest soil respiration in response to nitrogen deposition. Nat. Geosci. 3 (5), 315, 2010.

14. MO J., ZHANG W., ZHU W., GUNDERSEN P., FANG Y., LI D., WANG $H$. Nitrogen addition reduces soil respiration in a mature tropical forest in southern China. Global Change Biol. 14 (2), 403, 2008.

15. MICKS P., ABER J.D., BOONE R.D., DAVIDSON E.A. Short-term soil respiration and nitrogen immobilization response to nitrogen applications in control and nitrogenenriched temperate forests. Forest Ecol. Manag. 196 (1), 57, 2004.

16. CRAINE J.M., WEDIN D.A., REICH P.B. The response of soil $\mathrm{CO}_{2}$ flux to changes in atmospheric $\mathrm{CO}_{2}$, nitrogen supply and plant diversity. Global Change Biol. 7 (8), 947, 2001.

17. XU W., WAN S. Water- and plant-mediated responses of soil respiration to topography, fire, and nitrogen fertilization in a semiarid grassland in northern China. Soil Biol. Biochem. 40 (3), 679, 2008.

18. BURTON A.J., PREGITZER K.S., CRAWFORD J.N., ZOGG G.P., ZAK D.R. Simulated chronic $\mathrm{NO}_{3}^{-}$- deposition reduces soil respiration in northern hardwood forests. Global Change Biol. 10 (7), 1080, 2004.

19. DENG Q., CHENG X.L., ZHOU G.Y., LIU J.X., LIU S.Z., ZHANG Q.F., ZHANG D.Q.Seasonal responses of soil respiration to elevated $\mathrm{CO}_{2}$ and $\mathrm{N}$ addition in young subtropical forest ecosystem in southern China. Ecol. Eng. 61, 65, 2013.

20. GAO Q., HASSELQUIST N.J., PALMROTH S., ZHENG Z.M., YOU W.H.Short-term response of soil respiration to nitrogen fertilization in a subtropical evergreen forest. Soil Biol. Biochem. 76, 297, 2014.

21. PRUDEN G., POWLSON D.S., JENKINSON D.S. The measurement of ${ }^{15} \mathrm{~N}$ in soil and plant material. Fert. Res. 6 (3), 205, 1985

22. SUN Z.Z., LIU L., MA Y., YIN G., ZHAO C., ZHANG Y.The effect of nitrogen addition on soil respiration from a nitrogen-limited forest soil. Agr. Forest Meteorol. 197, 103, 2014.

23. KALEMBASA S.J., JENKINSON D.S. A comparative study of titrimetric and gravimetric methods for the determination of organic carbon in soil. J. Sci. Food. Agr. 24 (9), 1085, 1973.

24. VANCE E.D., BROOKES P.C., JENKINSON D.S. An extraction method for measuring soil microbial biomass $\mathrm{C}$. Soil Biol. Biochem. 19 (6), 703, 1987.

25. FAN J., WANG J.S., ZHAO B., WU L.H., ZHANG C.Y., ZHAO X.H., GADOW K.V.Effects of manipulated aboveand belowground organic matter input on soil respiration in a Chinese pine plantation. PloS One. 10 (5), 2015.
26. LIU W.X., XU W.H., HONG J.P., WAN S.Q.Interannual variability of soil microbial biomass and respiration in responses to topography, annual burning and $\mathrm{N}$ addition in a semiarid temperate steppe. Geoderma. 158 (3), 259, 2010.

27. JIA X.X., SHAO M.A., WEI X.R. Responses of soil respiration to $\mathrm{N}$ addition, burning and clipping in temperate semiarid grassland in northern China. Agri. Forest Meteorol. 166, 32, 2012.

28. LOWMAN M.D., SCHOWALTER T.D. Plant science in forest canopies-the first 30 years of advances and challenges (1980-2010). New Phytol. 194 (1), 12, 2012.

29. CLEVELAND C.C, TOWNSEND A.R. Nutrient additions to a tropical rain forest drive substantial soil carbon dioxide losses to the atmosphere. P. Nat. Acad. Sci. USA. 103 (27), 10316, 2006.

30. BOWDEN R.D., DAVIDSON E., SAVAGE K., ARABIA C., STEUDLER P. Chronic nitrogen additions reduce total soil respiration and microbial respiration in temperate forest soils at the Harvard Forest. Forest Ecol. .Manag. 196 (1), 43, 2004.

31. RAMIREZ K.S., CRAINE J.M., FIERER N. Nitrogen fertilization inhibits soil microbial respiration regardless of the form of nitrogen applied. Soil Biol. Biochem. 42 (12), 2336, 2010.

32. ZHANG C.P., NIU D.C., HALL S.J., WEN H.Y., LI X.D., FU H., WAN C.G., ELSER J.J. Effects of simulated nitrogen deposition on soil respiration components and their temperature sensitivities in a semiarid grassland. Soil Biol. Biochem. 75, 113, 2014.

33. ALLEN A.S., SCHLESINGER W.H. Nutrient limitations to soil microbial biomass and activity in loblolly pine forest. Soil Biol. Biochem. 36 (4), 581, 2004.

34. GAVRICHKOVA O., KUZYAKOV Y. Ammonium versus nitrate nutrition of Zeamays and Lupinusalbus: effect on root-derived $\mathrm{CO}_{2}$ efflux. Soil Biol. Biochem. 40 (11), 113, 2008.

35. RODEGHIERO M., CESCATTI A. Indirect partitioning of soil respiration in a series of evergreen forest ecosystems. Plant Soil. 284 (1-2), 7, 2006.

36. TU L.H., DAI H.Z., HU T.X., ZHANG J., LUO S.H. Effects of simulated nitrogen deposition on soil respiration in a Bambusapervariabilis $\times$ Dendrocalamopsi plantation in rainy area of West China. Chinese J. Appl. Ecol. 22 (4), 829, 2011.

37. SAMUELSON L., MATHEW R., STOKES T., FENG Y., AUBREY D., COLEMAN M. Soil and microbial respiration in a loblolly pine plantation in response to seven years of irrigation and fertilization. Forest Ecol. Manag. 258 (11), 2431, 2009.

38. FONTAINE S., BAROT S., BARRE P., BDIOUI N., MARY B., RUMPEL C. Stability of organic carbon in deep soil layers controlled by fresh carbon supply. Nature. 450 (7167), 277, 2007.

39. CHEN J. The short-time effects of nitrogen and sulfur deposition on Larixprincipis-rupprechtii plantation. Beijing Forestry University, 2016.

40. LI Y.Q., XU M., SUN O.J. CUI W.C. Effects of root and litter exclusion on soil $\mathrm{CO}_{2}$ efflux and microbial biomass in wet tropical forests. Soil Biol. Biochem. 36 (12), 2111, 2004.

41. MAGILL A.H., ABER J.D., CURRIE W.S., NADELHOFFER K.J., MARTIN M.E., MCDOWELL W.H., MELILLO J.M., STEUDLER P. Ecosystem response to 15 years of chronic nitrogen additions at the Harvard Forest LTER, Massachusetts, USA. Forest Ecol. Manag. 196 (1), 7, 2004. 
42. VIVANCO L., AUSTIN A.T. Nitrogen addition stimulates forest litter decomposition and disrupts species interactions in Patagonia, Argentina. Global Change Biol. 17 (5), 1963, 2011.

43. NORRIS M.D., AVIS P.G., REICH P.B., HOBBIE S.E. Positive feedbacks between decomposition and soil nitrogen availability along fertility gradients. Plant Soil. 367 (1-2), 347, 2013.

44. TU L.H., HU T.X., ZHANG J., LI, X.W., HU H.L., LIU L., XIAO Y.L. Nitrogen addition stimulates different components of soil respiration in a subtropical bamboo ecosystem. Soil Biol. Biochem. 58, 255, 2013.

45. WANG J.S., WU L., ZHANG C.Y., ZHAO X.H., BU W.S. Combined effects of nitrogen addition and organic matter manipulation on soil respiration in a Chinese pine forest. Environ. Sci. Pollut. R. 23 (22), 22701, 2016.
46. BUCHMANN N. Biotic and abiotic factors controlling soil respiration rates in Piceaabies stands. Soil Biol. Biochem. 32 (11), 1625, 2000.

47. RUEHR N.K., KNOHL A., BUCHMANN N. Environmental variables controlling soil respiration on diurnal, seasonal and annual time-scales in a mixed mountain forest in Switzerland. Biogeochemistry. 98 (1-3), 153, 2010.

48. RAICH J., SCHLESINGER W.H.The global carbon dioxide flux in soil respiration and its relationship to vegetation and climate. Tellus B. 44 (2), 81, 1992.

49. DAVIDSON E.A., BELK E., BOONE R.D. Soil water content and temperature as independent or confounded factors controlling soil respiration in a temperate mixed hardwood forest. Global Change Biol. 4 (2), 217, 1998.

50. LUO Y.Q., WAN S.Q., HUI D.F., WALLACE L.L. Acclimatization of soil respiration to warming in a tall grass prairie. Nature. 413 (6856), 622, 2001. 